\title{
Media Exposure and General Trust as Predictors of Post-traumatic Stress Disorder: Ten Years after the 5.12 Wenchuan Earthquake in China
}

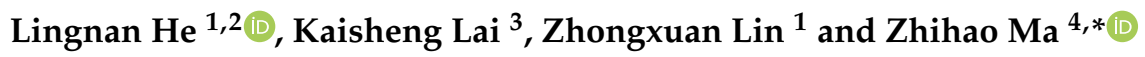 \\ 1 School of Communication and Design, Sun Yat-sen University, Guangzhou 510006, China; \\ heln3@mail.sysu.edu.cn (L.H.); lzhongx55@sina.com (Z.L.) \\ 2 Guangdong Key Laboratory for Big Data Analysis and Simulation of Public Opinion, Guangzhou 510006, \\ China \\ 3 School of Journalism and Communication, Jinan University, Guangzhou 510632, China; \\ kaishenglai@126.com \\ 4 Computational Communication Collaboratory, School of Journalism and Communication, \\ Nanjing University, Nanjing 210023, China \\ * Correspondence: redclass@163.com; Tel.: +86-175-6153-8460
}

Received: 3 October 2018; Accepted: 25 October 2018; Published: 27 October 2018

\begin{abstract}
There is a paucity of literature on the roles of media exposure, general trust, and their interactions in long-term post-traumatic stress disorder (PTSD) symptoms after a natural disaster. Trying to address this knowledge gap, our study aimed to (a) investigate whether exposure to media coverage during the traumatic event and general trust directly affected adult survivors' long-term PTSD symptoms 10 years after the 5.12 Wenchuan earthquake, and (b) to identify the potential differential pattern of the influence of media exposure on PTSD symptoms for adult survivors with various levels of general trust. Using cross-sectional methodology, we surveyed participants $(\mathrm{N}=1000)$ recruited from six disaster-affected counties. We assessed PTSD symptoms, media exposure, general trust, demographic characteristics, socioeconomic status, and earthquake exposure. Data were analyzed descriptively and with Tobit regression analyses. Reversed relationships between general trust and PTSD were verified, whereas no direct links were found between media exposure and PTSD. Interaction tests revealed that media exposure alleviated PTSD for high-trust survivors, but aggravated PTSD for low-trust survivors. These results suggest that general trust building should be considered in post-disaster construction activities.
\end{abstract}

Keywords: media exposure; general trust; post-traumatic stress disorder; earthquake; China; Sichuan/Wenchuan

\section{Introduction}

From 2006 to 2015, China had the highest number of people $(1,019,008,563)$ affected by disasters in the world [1]. This comprises $53 \%$ of disaster victims globally over the same period [1]. The 5.12 Wenchuan earthquake was the worst disaster that occurred in these years. The disaster caused 845.1 billion China Yuan (over 100 billion US dollars) in direct economic losses [2], 69,227 people died, 374,643 people were injured, and 17,923 people were missing [3]. As one typical and common mental disorder arising after exposure to natural disasters [4], post-traumatic stress disorder (PTSD) has been a key concern for both scholars and policymakers in the recent three decades [5-8]. One meta-analysis revealed that the prevalence of PTSD after earthquakes ranged from $4.10-67.07 \%$ in adults and from $2.50-60.00 \%$ in children [9]. It also demonstrated that being a woman, having lower socioeconomic status, and some earthquake exposure indicators were significant risk factors for developing PTSD 
symptoms [9]. Recently, as predictors of PTSD, media exposure and general trust have also received scholars' attention when examining the mental health consequences of terrorist incidents and regional wars [10-12]. Consequently, there is a need for an insightful framework to verify whether media exposure and general trust play key roles in the mental health consequences associated with the 5.12 Wenchuan earthquake.

PTSD was the most prevalent mental disorder for both rescuers and survivors of the 5.12 Wenchuan earthquake [13-15]. The prevalence of PTSD among adult survivors was reported as $62.8 \%$ in Qingchuan one month after the earthquake [16], 43\% in Mianzhu two months after the earthquake [13], and $37.8 \%$ and $13.0 \%$ in two temporary camp communities, respectively, in Beichuan three months after the earthquake [15]. In addition, children and adolescent survivors were affected by PTSD [17]; however, the results varied per survey site and among participants. One longitudinal study indicated that the prevalence of PTSD and PTSD symptoms declined over time [18]; however, PTSD may have lifelong persistence [19]—another study revealed that $29.6 \%$ of adolescent participants reported clinical symptoms of PTSD three years after the 5.12 Wenchuan earthquake [20]. Even for some adult survivors, PTSD was still highly prevalent for years. One study conducted in Beichuan eight years after the earthquake revealed that the prevalence of symptomalogical PTSD was $11.8 \%$ [16].

Ten years have passed since the earthquake, and many survivors may still have mental disorders. More research on the risk factors of long-term psychiatric outcomes is needed. Demographic variables, socioeconomic status, and disaster exposure are the most commonly considered risk factors to predict PTSD in traditional epidemiological and psychiatric approaches [9]. These factors are robust for short-term PTSD symptoms; however, they are inadequate for predicting long-term psychopathological consequences since people are assumed to be living with protentional lifelong exposure to traumatic events in today's informational society [21].

Linking exposure to media coverage of traumatic events and psychopathological consequences is one rational approach to understanding antecedents of long-term mental health effects of disasters [21]. There are two potential mechanisms to explain the role of media coverage in forming PTSD. The first is secondary traumatization, which implies that people may reexperience the traumatic event via media coverage, thus leading to mental disorders regardless of direct exposure to the event [22]. Following the events of September 11th in the United States, several studies indicated that media is the most common trigger of memory recall to evoke people's psychopathological outcomes [23-26]. Ahern and colleagues found that exposure to television coverage during the attack was strongly associated with viewers' PTSD symptoms four months after 11 September [23]. Silver and colleagues reported that media exposure behavior even predicted increased PTSD symptoms two to three years after 11 September [24]. Contrarily, the second mechanism is stress alleviation, which refers to people trying to seek more information about the traumatic event to reduce the perception of uncertainty and to alleviate stress $[27,28]$. Exposure to media coverage about the traumatic event is one typical coping strategy when people have harmful mental consequences after a traumatic event. A previous study implied that seeking information about September 11th may reduce negative emotion after the attack [27], whereas little evidence was found to support the assumption that media exposure relieved psychological stress. This finding raised the question of whether media exposure during the traumatic event is indeed traumatic, or if it acts as a mental buffer, and whether the PTSD symptoms associated with media exposure persist 10 years after the 5.12 Wenchuan earthquake for adult survivors. Given the link between media exposure and mental disorder outcomes that consistently emerges in the study area of PTSD after terrorist events, we hypothesized the following:

H1: Exposure to media coverage about the traumatic event during the disaster will be associated with PTSD symptoms among adult survivors 10 years after the 5.12 Wenchuan earthquake.

Another approach to predicate long-term PTSD symptoms is based on the social capital framework. As one umbrella concept of social connection process, social capital is a topic increasingly gaining attention from epidemiologists and political scientists to understand and improve mental 
health outcomes [29-31], including PTSD [5,32,33]. Social capital is also one crucial theoretical framework to operate disaster-related risk management [34,35]. Studies demonstrate that social capital was associated with better performance of decision-making process in public disaster protection projects and more efficient risk campaigns $[35,36]$.

Particular attention is paid to one important component—general trust [37]—which refers to trust in non-specific others [38], and its role in ameliorating disaster victims' mental disorders [5], increasing perceived self-efficacy [35], and providing social support during and after a disaster [35]. General trust was also shown to be positively associated with reduced health risk behaviors (e.g., smoking, alcohol drinking) [30,39], increased self-rated health [40], and palliated PTSD symptoms among survivors four years after an earthquake [5]. More importantly, one recent study revealed that general trust had a strong relationship with lifelong PTSD symptoms [32]. Scholars emphasize that strategies and intervention options for repairing trust for affected people are needed [32]. In the case of the 5.12 Wenchuan earthquake, it is possible that general trust could help alleviate long-term PTSD symptoms among disaster victims. Consequently, we hypothesized the following:

H2: General trust will be negatively associated with PTSD symptoms among adult survivors 10 years after the 5.12 Wenchuan earthquake.

This study has focused thus far on two factors associated with both individual and collective post-disaster coping strategies-media exposure and general trust-and their potential direct effects on long-term PTSD symptoms. However, in addition to drawing direct connections between these predictors of PTSD symptoms, previous studies also suggest that issues related to social trust were primary factors to explain how exposure to media coverage about risk events amplifies the social risk [41,42]. If disaster victims do not trust the media coverage during a disaster, their risk perception, reactions toward the disaster, and uncontrollability of subjective consciousness will be strengthened [41]. Hence, the role of trust may differ in various media environments. Moreover, the effects of information exchange on the risk perception of a disaster, which may be associated with increased mental disorders [43], were also moderated by victims' attitude towards specific risks [44]. These prior findings raised the question of whether these two concerned factors will be interactively associated with mental health outcomes.

The existing literature has yet to establish a theoretical framework to determine whether media exposure amplifies or diminishes the role of general trust in relieving PTSD symptoms among disaster victims. Further, empirical research has not investigated the buffering effect of general trust on exposure to media coverage of traumatic events in a mental health context. General trust is generally regarded as a social determinant of mental health, whereas the role of media exposure has resulted in inconsistent findings. Consequently, and given the complicated situation concerning the post-disaster rebuilding after the 5.12 Wenchuan earthquake, this study exploratorily assumes that general trust moderates the effects of media exposure on PTSD symptoms. We tested this with the following question:

RQ: Does how media exposure affects PTSD symptoms differ between adults who have a high level of general trust and those who have a low level of general trust?

\section{Materials and Methods}

\subsection{Sampling Procedures}

The survey team conducted a cross-sectional study across six counties in Sichuan in May 2018-the 10th anniversary of the 5.12 Wenchuan earthquake. The Chinese government divided all damaged areas into three categories: Heavily damaged, moderately damaged, and slightly damaged [45]. The six counties this study (see Figure 1) selected were two slightly damaged areas (Jingyang and Lizhou), two moderately damaged areas (Shunqing and Pengan), and two heavily damaged areas (Mianzhu and Qingchuan). In the initial field investigation, the survey team selected 26 communities according to the damage situations and residents' living arrangement after the earthquake. In the second stage of 
sampling, 30 to 50 individuals were selected within each settlement according to the local population size. Overall, data from 1000 adult survivors were included. Inclusion criteria were as follows: All participants were already adults and lived in the local county before the earthquake, and they did not migrate to other places longer than one year after the earthquake.

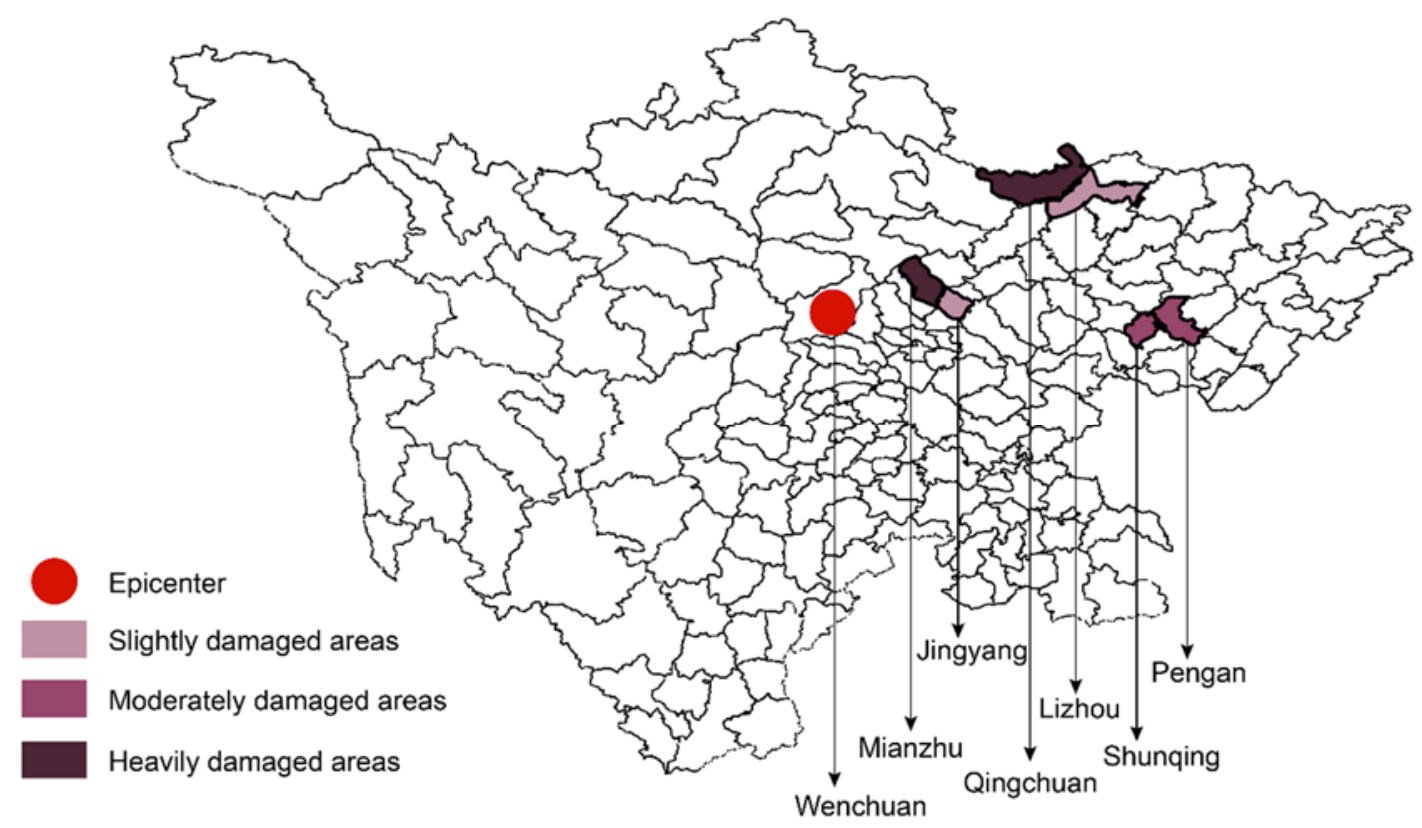

Figure 1. Map of survey regions.

\subsection{Measures}

\subsubsection{PTSD Symptoms}

The PTSD Check List-Civilian Version (PCL-C) was used to assess PTSD symptoms [46]. This instrument consists of 17 items that were developed according to the diagnostic criteria of PTSD set by the Diagnostic and Statistical Manual of Mental Diseases, fourth edition [46,47]. It presents three symptoms: Reexperiencing, avoidance, and arousal. The PCL-C has been shown to be reliable in diverse languages and has been validated in many countries, including China [48]. In this study, each item was measured from 1 to 5 ( $1=$ not at all bothered, $2=$ slightly, $3=$ moderately, $4=$ severely, and $5=$ extremely severely). In this study, Cronbach's alphas were 0.898 for the PCL-C, 0.712 for reexperiencing, 0.774 for avoidance, and 0.780 for arousal. Since we examined the links between media usage, general trust, and PTSD symptoms, the PCL-C overall score and its three sub-scores were calculated by the mean of related items.

\subsubsection{Media Exposure}

Based on the suggestions of previous researchers [49,50], media exposure was measured by a one-item media exposure scale. All participants were asked to estimate how many times they spent watching the news about the earthquake via media platforms (e.g., newspaper, broadcasting, television, Internet, etc.) in the following month after the 5.12 Wenchuan earthquake. Responses ranged from 1 (never) to 5 (a lot).

\subsubsection{General Trust}

General trust was also evaluated via a widely used one-item general trust scale [30,51]. All participants were asked to appraise the item, "Do you approve that most people in this society can be trusted?" Responses comprised the following: "do not agree", "neutral", "agree", and "do not know." 
This variable was dichotomized into "high trust" (1) and "low trust" (0), with the response, "agree", being the high trust group. Other responses were combined and given a 0 value.

\subsubsection{Control Variables}

We treated demographic variables, socioeconomic status, and earthquake exposure as control variables. Data collected included participants' gender, age, community status, marital status, educational background, annual household income, and 16 items about direct/indirect earthquake exposure developed by previous studies [52,53].

\subsection{Statistical Analysis}

Most previous studies estimated via the ordinary least squares strategy; however, there are definite boundaries (from 1 to 5 ) for dependent variables. In addition, the Jarque-Bera statistic (see Figure 2) demonstrates that the null hypothesis of normality is rejected at the $1 \%$ significance level [54]. These imply that regression models may be biased estimated via the ordinary least squares strategy.
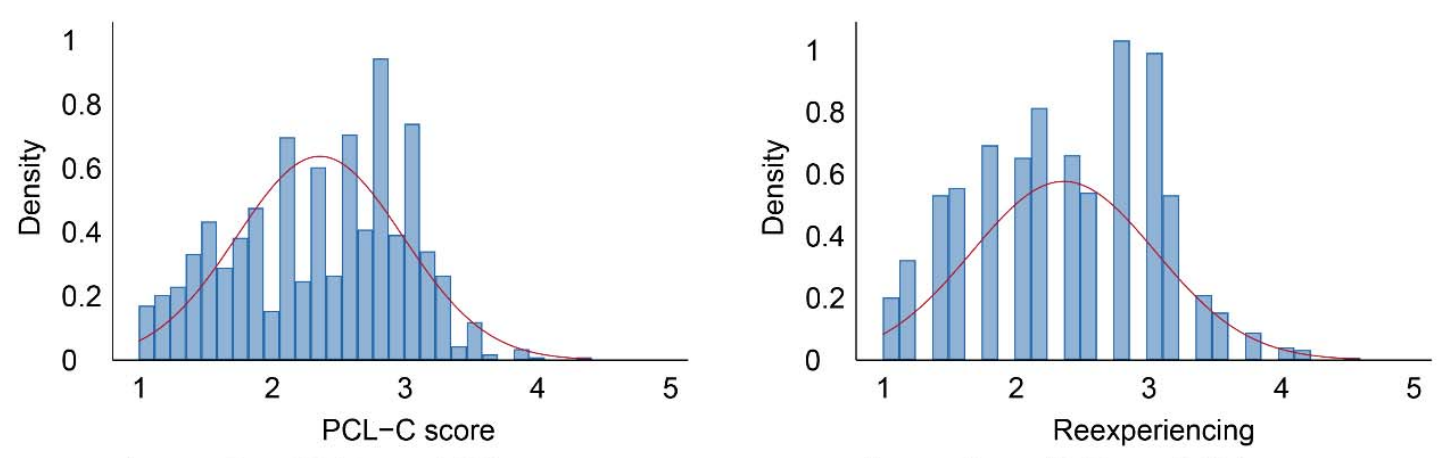

Jarque-Bera:32.04, $\mathrm{p}<0.001$

Jarque-Bera:18.37, $\mathrm{p}<0.001$
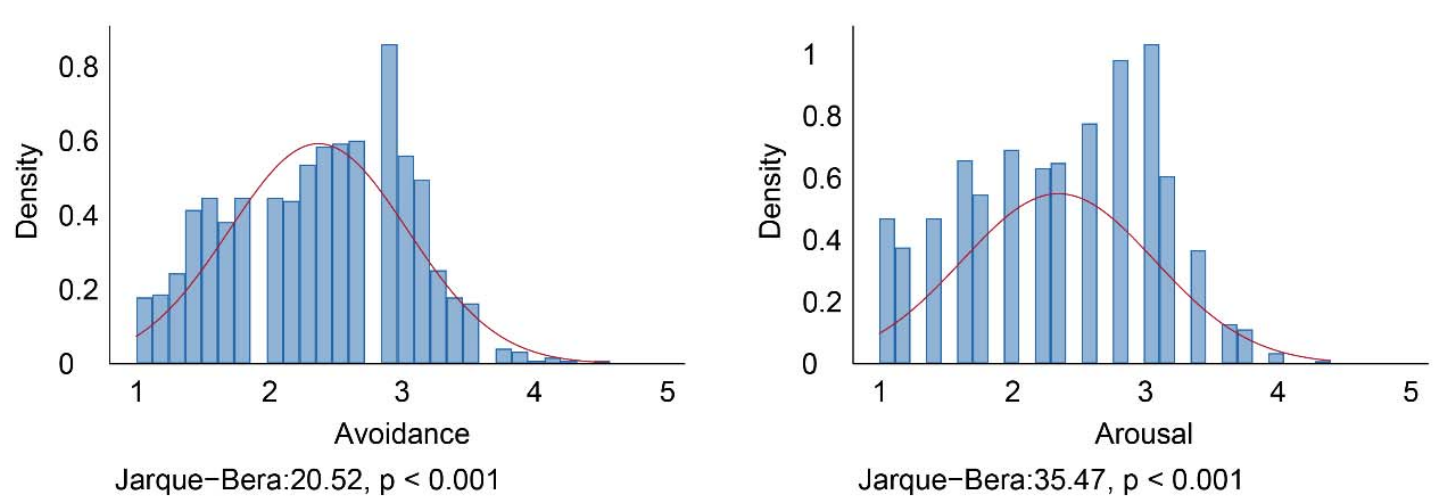

Figure 2. The Jarque-Bera statistic tests for the null hypothesis of normality for the distribution of the series.

Hence, this study adopted the Tobit regression model [55] to make this estimation as follows:

$$
\begin{aligned}
& \text { PTSD }_{i}^{*}=\beta_{0}+\beta_{1} \text { Media }_{i}+\beta_{2} \text { Trust }_{i}+\beta_{3} X_{i}+\varepsilon_{i} \\
& \operatorname{PTSD}_{i}=\left\{\begin{array}{rr}
5 & \text { if } \mathrm{PTSD}_{i}^{*}>5 \\
\text { PTSD }_{i}^{*} & \text { if } 1<\mathrm{PTSD}_{i}^{*} \leq 5 \\
1 & \text { if } \mathrm{PTSD}_{i}^{*} \leq 1
\end{array}\right.
\end{aligned}
$$

$P T S D_{i}$ in Equation (1) shows the estimated PTSD status for individual $i$; $P T S D_{i}^{*}$ is the direct expected value for observations; $\mathrm{Media}_{i}$ is the media exposure status for individual $i$; Trust $_{i}$ is the general trust for individual $i ; X_{i}$ is the vector of control variables; $\varepsilon_{i}$ is the independently distributed error term; and $\beta_{1}$ and $\beta_{2}$ are target coefficients, which will be estimated for testing two research hypotheses. 
To answer the research question, "How media exposure affects PTSD symptoms differ between adults who have a high level of general trust and those who have a low level of general trust?", we added an interaction item into the estimation:

$$
\text { PTSD }_{i}^{*}=\alpha_{0}+\alpha_{1} \text { Media }_{i}+\alpha_{2} \text { Trust }_{i}+\alpha_{3} \text { Media }_{i} * \text { Trust }_{i}+\alpha_{4} X_{i}+\omega_{i}
$$

Media $_{i} *$ Trust $_{i}$ in Equation (2) is the interaction item of media exposure and general trust for individual $i$, and $\alpha_{3}$ is the target coefficient that will provide the evidence about this research question.

\section{Results}

\subsection{Participants' Characteristics}

Table 1 shows descriptive statistics results for a variety of measures of PTSD symptoms, independent variables, demographic and socioeconomic variables, and earthquake exposure. Overall, $43.5 \%$ were male, $55.7 \%$ were living in rural sites, $82.7 \%$ were married, and the mean age was 46 years ( $\mathrm{SD}=12$ years). The minority of participants had attended associate college and above (25.3\%). Further, the proportion of higher annual household income (90,000 RMB and above) was low (22.1\%). The PCL-C score and three PTSD symptoms scores were less than 3 , which is the average score of the cut-off point to identify PTSD. Participants showed a moderate amount of media exposure in the following month after the earthquake. Additionally, $57.5 \%$ displayed a high level of general trust. For the earthquake exposure situation, most participants experienced moderate (42\%) to serious $(31 \%)$ loss of property. The prevalence of the other 15 indicators of earthquake exposure ranged from $1.8 \%$ (being disabled) to $42.3 \%$ (acquaintance injured).

Table 1. Descriptive statistics.

\begin{tabular}{|c|c|c|c|c|c|}
\hline Variable & Obs & Mean & Std.Dev. & Min & Max \\
\hline \multicolumn{6}{|l|}{ PTSD symptoms } \\
\hline PCL-C score & 1000 & 2.364 & 0.626 & 1 & 4.412 \\
\hline Reexperiencing & 1000 & 2.364 & 0.692 & 1 & 4.6 \\
\hline Avoidance & 1000 & 2.374 & 0.673 & 1 & 4.571 \\
\hline Arousal & 1000 & 2.349 & 0.726 & 1 & 4.4 \\
\hline \multicolumn{6}{|l|}{ Independent variables } \\
\hline Media exposure & 1000 & 3.765 & 0.985 & 1 & 5 \\
\hline General trust $(0=$ low trust $)$ & 1000 & 0.575 & 0.495 & 0 & 1 \\
\hline \multicolumn{6}{|c|}{ Demographic and socioeconomic variables } \\
\hline Male & 1000 & 0.435 & 0.496 & 0 & 1 \\
\hline Age & 1000 & 45.618 & 11.628 & 28 & 74 \\
\hline Rural site & 1000 & 0.557 & 0.497 & 0 & 1 \\
\hline Married & 1000 & 0.827 & 0.378 & 0 & 1 \\
\hline \multicolumn{6}{|c|}{ Educational background $(0=$ primary school and below $)$} \\
\hline Junior high school & 1000 & 0.313 & 0.464 & 0 & 1 \\
\hline Senior high school & 1000 & 0.277 & 0.448 & 0 & 1 \\
\hline Associate college and above & 1000 & 0.253 & 0.435 & 0 & 1 \\
\hline \multicolumn{6}{|c|}{ Annual household income $(0=$ less than $40,000 \mathrm{RMB})$} \\
\hline $40,000-59,999$ RMB & 1000 & 0.286 & 0.452 & 0 & 1 \\
\hline 60,000-89,999 RMB & 1000 & 0.255 & 0.436 & 0 & 1 \\
\hline $90,000 \mathrm{RMB}$ and above & 1000 & 0.221 & 0.415 & 0 & 1 \\
\hline \multicolumn{6}{|l|}{ Earthquake exposure } \\
\hline Being buried & 1000 & 0.024 & 0.153 & 0 & 1 \\
\hline Being injured & 1000 & 0.152 & 0.359 & 0 & 1 \\
\hline Being disabled & 1000 & 0.018 & 0.133 & 0 & 1 \\
\hline Family died & 1000 & 0.057 & 0.232 & 0 & 1 \\
\hline Family injured & 1000 & 0.218 & 0.413 & 0 & 1 \\
\hline Family disabled & 1000 & 0.061 & 0.239 & 0 & 1 \\
\hline Kinsfolk died & 1000 & 0.138 & 0.345 & 0 & 1 \\
\hline
\end{tabular}


Table 1. Cont.

\begin{tabular}{cccccc}
\hline Variable & Obs & Mean & Std.Dev. & Min & Max \\
\hline Kinsfolk injured & 1000 & 0.388 & 0.488 & 0 & 1 \\
Kinsfolk disabled & 1000 & 0.179 & 0.384 & 0 & 1 \\
Acquaintance died & 1000 & 0.197 & 0.398 & 0 & 1 \\
Acquaintance injured & 1000 & 0.423 & 0.494 & 0 & 1 \\
Acquaintance disabled & 1000 & 0.303 & 0.460 & 0 & 1 \\
Witness to others' bury & 1000 & 0.130 & 0.336 & 0 & 1 \\
Witness to others' death & 1000 & 0.232 & 0.422 & 0 & 1 \\
Witness to others' injury & 1000 & 0.360 & 0.480 & 0 & 1 \\
Loss of house and property (0 = mildly) & & & & & \\
Moderate & 1000 & 0.420 & 0.494 & 0 & 1 \\
Serious & 1000 & 0.310 & 0.463 & 0 & 1 \\
\hline
\end{tabular}

\subsection{Main Effects}

Table 2 provides an overall picture of the main effect of the regression estimates. Prior to reporting the results of our hypotheses tests, we first illustrate the Tobit estimates of PCL-C score and three PTSD symptoms, based on demographic variables, socioeconomic status, and earthquake exposure status for all 1000 valid participants (via Models 1, 3, 5, and 7 of Table 2).

There was also a strong education gradient: Higher education corresponded to increased PCL-C scores and three PTSD symptoms. This finding contradicts one recent meta-analysis [9]. One likely explanation is that the long-term PTSD symptoms may be diminished over time much easier for people with less education than their higher educated counterparts. For those higher educated survivors, the buffer effect of education on mental disorders may be extruded.

Earthquake exposure related indicators show complicated relationships with PTSD symptoms. Being injured was negatively related to PCL-C score $(\beta=-0.13, p<0.05)$, avoidance $(\beta=-0.14$, $p<0.05)$, and arousal $(\beta=-0.17, p<0.05)$; family injured was positively related to PCL-C score $(\beta=0.12, p<0.05)$, reexperiencing $(\beta=0.19, p<0.01)$, and arousal $(\beta=0.12, p<0.1)$; family disabled was negatively related to reexperiencing $(\beta=-0.17, p<0.1)$; kinsfolk died was negatively related to all outcome variables ( $\beta$ s ranged from -0.19 to -0.11 , all $p \mathrm{~s}<0.1$ ); kinsfolk disabled was negatively related to reexperiencing $(\beta=-0.11, p<0.1)$; acquaintance died was positively related to PCL-C score $(\beta=-0.12, p<0.05)$, avoidance $(\beta=-0.14, p<0.01)$, and arousal $(\beta=-0.14, p<0.05)$; witness to others' burial was negatively related to PCL-C score $(\beta=-0.11, p<0.1)$ and reexperiencing $(\beta=-0.13$, $p<0.05)$; and witness to others' death was negatively related to PCL score $(\beta=-0.09, p<0.1)$, avoidance $(\beta=-0.10, p<0.05)$, and arousal $(\beta=-0.12, p<0.05)$. Participants who reported higher levels of house and property loss had worse PTSD symptoms than those with lower levels.

There were not any coefficients of media exposure in Models 2, 4, 6, or 8, as shown in Table 2, which shows significant results ( $\beta$ s ranged from -0.03 to 0.01 , all $p s>0.05$ ). Hence, H1 was not supported. Further, general trust was significantly negatively associated with PCL-C score $(\beta=-0.12$, $p<0.01)$, reexperiencing $(\beta=-0.08, p<0.1)$, avoidance $(\beta=-0.13, p<0.01)$, and arousal $(\beta=-0.16$, $p<0.001$ ), indicating general trust is a key predictor of long-term PTSD symptoms among adult survivors 10 years after the 5.12 Wenchuan earthquake. Thus, $\mathrm{H} 2$ was statistically corroborated. 
Table 2. Tobit model of predicting PTSD symptoms.

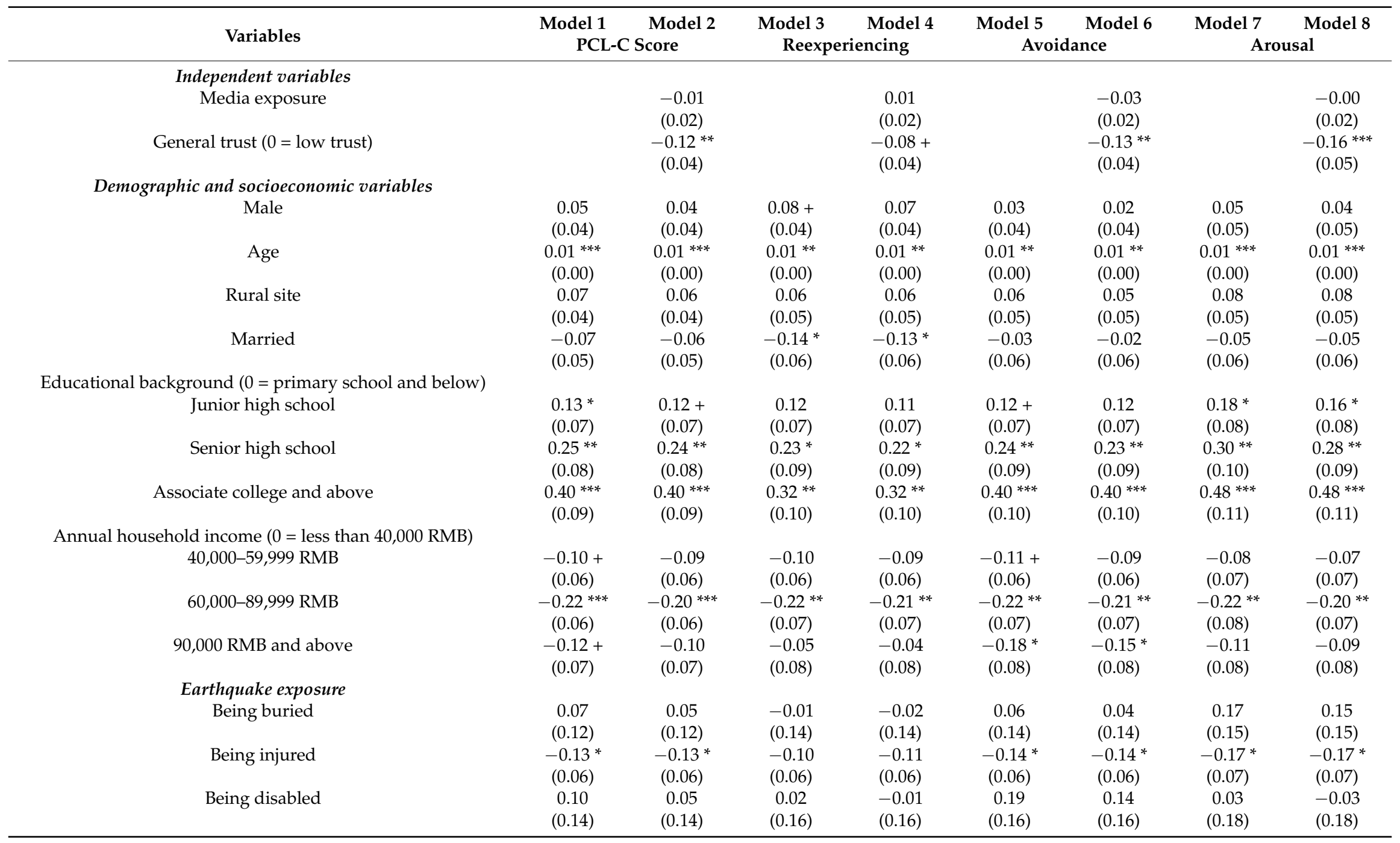


Table 2. Cont

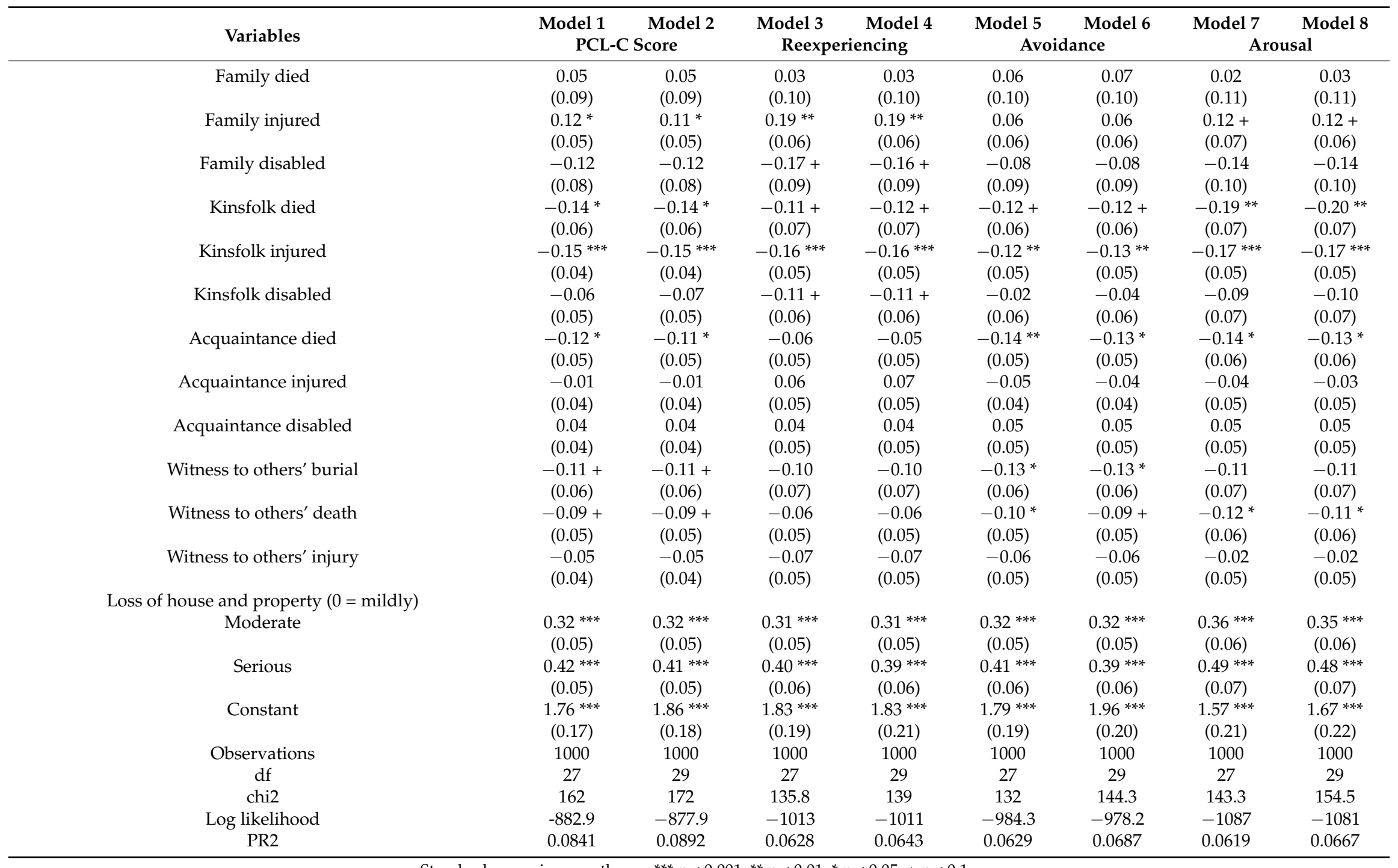

Standard errors in parentheses; ${ }^{* * *} p<0.001,{ }^{* *} p<0.01,{ }^{*} p<0.05,+p<0.1$. 


\subsection{Interaction Effects}

Table 3 shows the results of the Tobit estimates of the PCL-C score and three PTSD symptoms, with an extra predictor of the interaction item of media exposure and general trust to answer the research question proposed above. Coefficients of the interaction item in Model $1(\beta=-0.07, p<0.1)$ and Model $4(\beta=-0.10, p<0.05)$ were negatively, marginally significant, which demonstrates that, compared with participants who had low trust, PCL-C score and arousal among participants with high trust were mitigated via exposure to media coverage about the disaster during the earthquake. Whereas, the interaction item in Models 2 and 3 was not significantly related to the outcome variables.

Table 3. Interaction effects of media exposure and general trust on PTSD symptoms.

\begin{tabular}{|c|c|c|c|c|}
\hline Variables & $\begin{array}{c}\text { Model } 1 \\
\text { PCL-C Score }\end{array}$ & $\begin{array}{c}\text { Model } 2 \\
\text { Reexperiencing }\end{array}$ & $\begin{array}{c}\text { Model } 3 \\
\text { Avoidance }\end{array}$ & $\begin{array}{l}\text { Model } 4 \\
\text { Arousal }\end{array}$ \\
\hline \multicolumn{5}{|l|}{ Interaction Item } \\
\hline Media exposure $\times$ General trust & $\begin{array}{c}-0.07+ \\
(\mathbf{0 . 0 4 )}\end{array}$ & $\begin{array}{l}-0.06 \\
\mathbf{( 0 . 0 4 )}\end{array}$ & $\begin{array}{l}-0.06 \\
\mathbf{( 0 . 0 4 )}\end{array}$ & $\begin{array}{c}-0.10^{*} \\
(0.05)\end{array}$ \\
\hline \multicolumn{5}{|l|}{ Independent variables } \\
\hline Media exposure & $\begin{array}{c}0.03 \\
(0.03)\end{array}$ & $\begin{array}{c}0.05 \\
(0.03)\end{array}$ & $\begin{array}{c}0.00 \\
(0.03)\end{array}$ & $\begin{array}{c}0.05 \\
(0.04)\end{array}$ \\
\hline General trust $(0=$ low trust $)$ & $\begin{array}{c}0.14 \\
(0.15)\end{array}$ & $\begin{array}{c}0.15 \\
(0.17)\end{array}$ & $\begin{array}{c}0.08 \\
(0.16)\end{array}$ & $\begin{array}{c}0.21 \\
(0.18)\end{array}$ \\
\hline \multicolumn{5}{|c|}{ Demographic and socioeconomic variables } \\
\hline Male & $\begin{array}{c}0.04 \\
(0.04)\end{array}$ & $\begin{array}{c}0.06 \\
(0.04)\end{array}$ & $\begin{array}{c}0.02 \\
(0.04)\end{array}$ & $\begin{array}{c}0.03 \\
(0.05)\end{array}$ \\
\hline Age & $\begin{array}{c}0.01^{* * *} \\
(0.00)\end{array}$ & $\begin{array}{l}0.01 * * \\
(0.00)\end{array}$ & $\begin{array}{l}0.01 * * \\
(0.00)\end{array}$ & $\begin{array}{c}0.01^{* * *} \\
(0.00)\end{array}$ \\
\hline Rural site & $\begin{array}{c}0.06 \\
(0.04)\end{array}$ & $\begin{array}{c}0.06 \\
(0.05)\end{array}$ & $\begin{array}{c}0.05 \\
(0.05)\end{array}$ & $\begin{array}{c}0.08 \\
(0.05)\end{array}$ \\
\hline Married & $\begin{array}{l}-0.06 \\
(0.05)\end{array}$ & $\begin{array}{c}-0.14^{*} \\
(0.06)\end{array}$ & $\begin{array}{l}-0.02 \\
(0.06)\end{array}$ & $\begin{array}{l}-0.05 \\
(0.06)\end{array}$ \\
\hline \multicolumn{5}{|c|}{ Educational background ( $0=$ primary school and below $)$} \\
\hline Junior high school & $\begin{array}{l}0.12+ \\
(0.06)\end{array}$ & $\begin{array}{c}0.11 \\
(0.07)\end{array}$ & $\begin{array}{c}0.11 \\
(0.07)\end{array}$ & $\begin{array}{l}0.16 * \\
(0.08)\end{array}$ \\
\hline Senior high school & $\begin{array}{l}0.24 * * \\
(0.08)\end{array}$ & $\begin{array}{l}0.22 * \\
(0.09)\end{array}$ & $\begin{array}{c}0.23 * * \\
(0.09)\end{array}$ & $\begin{array}{l}0.29 * * \\
(0.09)\end{array}$ \\
\hline Associate college and above & $\begin{array}{c}0.40^{* * *} \\
(0.09)\end{array}$ & $\begin{array}{l}0.32 * * \\
(0.10)\end{array}$ & $\begin{array}{c}0.40^{* * *} \\
(0.10)\end{array}$ & $\begin{array}{c}0.48^{* * *} \\
(0.11)\end{array}$ \\
\hline \multicolumn{5}{|c|}{ Annual household income ( $0=$ less than 40,000 RMB $)$} \\
\hline $40,000-59,999 \mathrm{RMB}$ & $\begin{array}{l}-0.08 \\
(0.06)\end{array}$ & $\begin{array}{l}-0.09 \\
(0.06)\end{array}$ & $\begin{array}{l}-0.09 \\
(0.06)\end{array}$ & $\begin{array}{l}-0.06 \\
(0.07)\end{array}$ \\
\hline $60,000-89,999 \mathrm{RMB}$ & $\begin{array}{c}-0.20 * * \\
(0.06)\end{array}$ & $\begin{array}{c}-0.21^{* *} \\
(0.07)\end{array}$ & $\begin{array}{c}-0.20 * * \\
(0.07)\end{array}$ & $\begin{array}{c}-0.20^{* *} \\
(0.07)\end{array}$ \\
\hline 90,000 RMB and above & $\begin{array}{l}-0.09 \\
(0.07)\end{array}$ & $\begin{array}{l}-0.03 \\
(0.08)\end{array}$ & $\begin{array}{c}-0.15+ \\
(0.08)\end{array}$ & $\begin{array}{l}-0.08 \\
(0.08)\end{array}$ \\
\hline \multicolumn{5}{|l|}{ Earthquake exposure } \\
\hline Being buried & $\begin{array}{c}0.06 \\
(0.12)\end{array}$ & $\begin{array}{c}-0.02 \\
(0.14)\end{array}$ & $\begin{array}{c}0.05 \\
(0.14)\end{array}$ & $\begin{array}{c}0.16 \\
(0.15)\end{array}$ \\
\hline Being injured & $\begin{array}{c}-0.14^{*} \\
(0.06)\end{array}$ & $\begin{array}{c}-0.11+ \\
(0.06)\end{array}$ & $\begin{array}{c}-0.14^{*} \\
(0.06)\end{array}$ & $\begin{array}{c}-0.17^{*} \\
(0.07)\end{array}$ \\
\hline Being disabled & $\begin{array}{c}0.04 \\
(0.14)\end{array}$ & $\begin{array}{l}-0.01 \\
(0.16)\end{array}$ & $\begin{array}{c}0.14 \\
(0.16)\end{array}$ & $\begin{array}{l}-0.03 \\
(0.17)\end{array}$ \\
\hline Family died & $\begin{array}{c}0.06 \\
(0.09)\end{array}$ & $\begin{array}{c}0.04 \\
(0.10)\end{array}$ & $\begin{array}{c}0.08 \\
(0.10)\end{array}$ & $\begin{array}{c}0.04 \\
(0.11)\end{array}$ \\
\hline Family injured & $\begin{array}{l}0.12 \text { * } \\
(0.05)\end{array}$ & $\begin{array}{c}0.20 * * \\
(0.06)\end{array}$ & $\begin{array}{c}0.06 \\
(0.06)\end{array}$ & $\begin{array}{c}0.13+ \\
(0.06)\end{array}$ \\
\hline Family disabled & $\begin{array}{l}-0.12 \\
(0.08)\end{array}$ & $\begin{array}{c}-0.16+ \\
(0.09)\end{array}$ & $\begin{array}{c}-0.08 \\
(0.09)\end{array}$ & $\begin{array}{c}-0.14 \\
(0.10)\end{array}$ \\
\hline Kinsfolk died & $\begin{array}{c}-0.14 \text { * } \\
(0.06)\end{array}$ & $\begin{array}{c}-0.12+ \\
(0.07)\end{array}$ & $\begin{array}{c}-0.12+ \\
(0.06)\end{array}$ & $\begin{array}{c}-0.20 \text { ** } \\
(0.07)\end{array}$ \\
\hline Kinsfolk injured & $\begin{array}{c}-0.16^{* * *} \\
(0.04)\end{array}$ & $\begin{array}{c}-0.16^{* * *} \\
(0.05)\end{array}$ & $\begin{array}{c}-0.13^{* *} \\
(0.05)\end{array}$ & $\begin{array}{c}-0.18^{* * *} \\
(0.05)\end{array}$ \\
\hline Kinsfolk disabled & $\begin{array}{l}-0.08 \\
(0.05)\end{array}$ & $\begin{array}{c}-0.12+ \\
(0.06)\end{array}$ & $\begin{array}{c}-0.04 \\
(0.06)\end{array}$ & $\begin{array}{l}-0.11 \\
(0.07)\end{array}$ \\
\hline
\end{tabular}


Table 3. Cont.

\begin{tabular}{|c|c|c|c|c|}
\hline Variables & $\begin{array}{c}\text { Model } 1 \\
\text { PCL-C Score }\end{array}$ & $\begin{array}{c}\text { Model } 2 \\
\text { Reexperiencing }\end{array}$ & $\begin{array}{c}\text { Model } 3 \\
\text { Avoidance }\end{array}$ & $\begin{array}{l}\text { Model } 4 \\
\text { Arousal }\end{array}$ \\
\hline Acquaintance died & $\begin{array}{l}-0.11 * \\
(0.05)\end{array}$ & $\begin{array}{l}-0.05 \\
(0.05)\end{array}$ & $\begin{array}{c}-0.12 * \\
(0.05)\end{array}$ & $\begin{array}{l}-0.13^{*} \\
(0.06)\end{array}$ \\
\hline Acquaintance injured & $\begin{array}{l}-0.01 \\
(0.04)\end{array}$ & $\begin{array}{c}0.06 \\
(0.05)\end{array}$ & $\begin{array}{l}-0.05 \\
(0.04)\end{array}$ & $\begin{array}{l}-0.03 \\
(0.05)\end{array}$ \\
\hline Acquaintance disabled & $\begin{array}{c}0.04 \\
(0.04)\end{array}$ & $\begin{array}{c}0.04 \\
(0.05)\end{array}$ & $\begin{array}{c}0.05 \\
(0.05)\end{array}$ & $\begin{array}{l}0.05 \\
(0.05)\end{array}$ \\
\hline Witness to others' burial & $\begin{array}{c}-0.11+ \\
(0.06)\end{array}$ & $\begin{array}{l}-0.10 \\
(0.07)\end{array}$ & $\begin{array}{c}-0.13^{*} \\
(0.06)\end{array}$ & $\begin{array}{l}-0.11 \\
(0.07)\end{array}$ \\
\hline Witness to others' death & $\begin{array}{c}-0.09+ \\
(0.05)\end{array}$ & $\begin{array}{l}-0.06 \\
(0.05)\end{array}$ & $\begin{array}{c}-0.10+ \\
(0.05)\end{array}$ & $\begin{array}{l}-0.12 * \\
(0.06)\end{array}$ \\
\hline Witness to others' injury & $\begin{array}{l}-0.05 \\
(0.04)\end{array}$ & $\begin{array}{l}-0.07 \\
(0.05)\end{array}$ & $\begin{array}{l}-0.05 \\
(0.05)\end{array}$ & $\begin{array}{l}-0.02 \\
(0.05)\end{array}$ \\
\hline \multicolumn{5}{|c|}{ Loss of house and property $(0=$ mildly $)$} \\
\hline Moderate & $\begin{array}{l}0.32 * * * \\
(0.05)\end{array}$ & $\begin{array}{l}0.31^{* * *} \\
(0.05)\end{array}$ & $\begin{array}{l}0.32 * * * \\
(0.05)\end{array}$ & $\begin{array}{c}0.35^{* * *} \\
(0.06)\end{array}$ \\
\hline Serious & $\begin{array}{l}0.41^{* * *} \\
(0.05)\end{array}$ & $\begin{array}{l}0.40^{* * *} \\
(0.06)\end{array}$ & $\begin{array}{l}0.39^{* * *} \\
(0.06)\end{array}$ & $\begin{array}{c}0.48^{* * *} \\
(0.07)\end{array}$ \\
\hline Constant & $\begin{array}{l}1.71^{* * *} \\
(0.20)\end{array}$ & $\begin{array}{l}1.70^{* * *} \\
(0.23)\end{array}$ & $\begin{array}{l}1.84^{* * *} \\
(0.22)\end{array}$ & $\begin{array}{l}1.46^{* * *} \\
(0.24)\end{array}$ \\
\hline Observations & 1000 & 1000 & 1000 & 1000 \\
\hline Df & 30 & 30 & 30 & 30 \\
\hline chi2 & 175.3 & 141 & 146.2 & 159 \\
\hline Log likelihood & -876.2 & -1010 & -977.3 & -1079 \\
\hline PR2 & 0.0909 & 0.0652 & 0.0696 & 0.0686 \\
\hline
\end{tabular}

To observe detailed information of these moderating effects, Figure 3 shows patterns of interaction effects with slope variations for people with low trust and people with high trust separately (separate Tobit regression results can be found in Table A1 of Appendix A). Figure 3a shows a negative slope for high trust participants and a positive slop for low trust participants. This pattern reveals that media exposure during the disaster alleviated the PCL-C score for high trust survivors, whereas it aggravated low trust survivors' PCL-C score. Figure $3 \mathrm{~b}$ shows a similar pattern-the most significant difference is that the line of high trust participants is much flatter, which means that media exposure slightly decreases the reexperiencing symptom for high trust survivors. Figure $3 \mathrm{c}$ shows a reversed pattern-the line of low trust participants is flat, which indicates that media exposure does not correlate with the avoidance symptoms of low trust survivors. Figure $3 \mathrm{~d}$ also shows a similar pattern with Figure 3a-for high trust survivors, arousal symptoms decreased with more exposure to media coverage about the disaster during the earthquake; whereas, for low trust survivors, increased media exposure corresponded to a significant increase in arousal symptoms. 

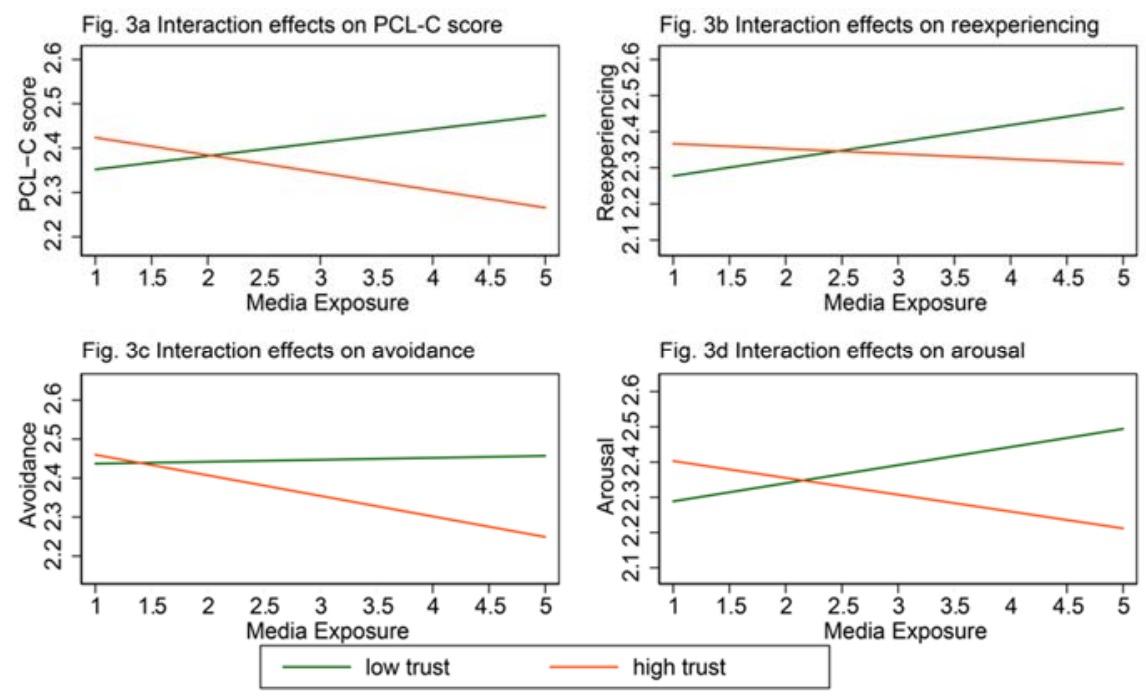

Figure 3. Interaction effects of media exposure and general trust on PTSD symptoms.

\section{Discussion}

To the best of our knowledge, this is the first study concerning media exposure and general trust as predictors of PTSD symptoms in a natural disaster context. It also provides sophisticated information to understand the psychopathological consequences of the 5.12 Wenchuan earthquake for adult survivors 10 years later.

Regarding media exposure, we found no direct link between media exposure to coverage of the disaster and long-term PTSD symptoms. This is inconsistent with most previous studies, which demonstrated positive relationships between media exposure and worse psychopathological consequences [56-58]. There are two possible explanations for this inconsistency. One simple explanation would be that the media exposure during the disaster may affect survivors' mental outcomes in a short-term period, whereas, these direct linkages cannot persist for 10 years. The second explanation is that, during the disaster, survivors lived in temporary shelters and experienced fear, anxiety, and depression [20,59]. Media exposure is just one coping strategy to reduce information uncertainty, which can be motivated by a short-term mental disorder and directly affected by earthquake exposure $[15,17]$. Certainly, there was some conclusive evidence revealed in the interaction tests, which will be discussed shortly.

As predicted, associations between general trust and long-term PTSD symptoms were strongly reversed. These results are consistent with previous studies that demonstrated a positive relationship between general trust and individual health outcomes [32,60]. General trust is a typical social interaction indicator of modern civil society [61], whereas traditional Chinese society has a differential pattern of trust that implies that the trust usually has hierarchical variations according to whether people have a kinship relationship [62]. Scholars believed the differential pattern of trust derived from traditional Confucians culture, which was verified as leading to worse general trust [63]. In the post-disaster construction process, traditional social norms and social connections were modified by outside forces and resources. New roles for the general trust have emerged taking precedence over traditional norms. People with a high level of general trust have more opportunities to participate in post-disaster rebuilding activities and therefore displayed increased positive psychological well-being. Whereas, building general trust in the process of post-disaster reconstruction may be difficult, especially for survivors who are female, low income, disabled, and have experienced a serious loss of house and property (see Table A2 in Appendix B).

The interaction tests provided novel evidence to understand how media exposure affects PTSD symptoms differently between adult survivors who have high vs. low levels of general trust. We hypothesized that media exposure would act as a coping strategy to reduce uncertainty during the disaster. Previous studies indicated a key motivation of seeking information is the negative 
emotions that are sparked during a disaster $[27,28]$. Most media coverage focused on real-time rescue situations and casualties. High trust survivors viewed media coverage and obtained adequate mental compensations according to the selective exposure hypothesis, which emphasizes that people prefer to receive information that is consistent with their attitudes [64]. Correspondingly, survivors who had a low level of general trust were more likely to seek negative information about the disaster relief system and post-disaster rebuilding activities via rumors or gossips. Hence, future mental health promotion programs should incorporate strategies that can not only use media coverage to deliver supporting information, but also develop a social trust system that can help survivors access media effectively and obtain potential psychological benefits.

This study had some limitations. First, the cross-sectional design limits our ability to infer causation regarding long-term PTSD. Future studies may consider a panel design to collect longitudinal data. Second, although we followed suggestions from previous studies [30,49-51], two one-item measures to measure general trust and media exposure may not fully capture the multidimensional aspects of these constructs. Although it is difficult for participants to recall detailed media exposure from 10 years ago, diverse media platforms may play distinct roles in forming long-term mental disorders. Future studies may consider this point using a similar study design and develop a valid measurement based on some sophisticated measurement, such as the Media Attentiveness Scale [65]. Also, as we discussed, the low-trust and high-trust survivors might selectively expose themselves to different media contents or selectively internalize different information from the same media contents. Future study may concern the measurement of survivors' media preferences and their perceived media credibility during the post-disaster period. Third, although we surveyed people from six counties to provide disaster area diversity, participants were not recruited via a random sampling method. This may weaken the overall representativeness of this study. Lastly, PTSD symptoms were measured using the PCL-C, which is not a clinical diagnostic method. As one previous study suggested, future studies may consider strengthening study validity and credibility via adopting a clinical diagnostic measurement [16].

\section{Conclusions}

In summary, we found a significant association between general trust and long-term PTSD symptoms among adult survivors 10 years after the 5.12 Wenchuan earthquake. General trust moderated linkages between exposure to media coverage about the disaster during the earthquake and long-term PTSD symptoms, indicating that media exposure can alleviate PTSD for high-trust survivors, but aggravate PTSD for low-trust survivors. These results suggest that general trust building should be considered in future post-disaster construction activities.

Furthermore, building general trust for victims and first responders cannot be separated from governmental interventions. As Steinhardt found, in Chinese society, general trust was directly contributed by the institutional confidence, which refers to the confidence in the civil service and courts and the perceived degree of corruption in local governments [66]. These imply that when a local government responds slowly to a disaster, dissatisfaction and discontent toward it can increase and this could weaken general trust. Moreover, disaster-affected individuals may be more competitive over limited resources, resulting in conflicts among them. Consequently, the net effects of disasters on general trust levels may vary based on the speed of government responses to disasters and the active support for the victims from local communities. Both neighborhood level and institutional level interventions should be allocated appropriately.

Author Contributions: Project administration, Z.M.; Supervision, Z.L.; Writing-original draft, L.H.; Writing-review \& editing, K.L.

Funding: This study was supported by the Natural Science Foundation of Guangdong Province of China (Grant No. 2018030310116) and by a grant from the State Ethnic Affairs Commission of China (Grant No. 2018-GMC-008).

Acknowledgments: Authors appreciate two anonymous reviewers for their valuable comments.

Conflicts of Interest: The authors declare that they have no conflict of interest. 


\section{Appendix A}

Table A1. Tobit model of predicting PTSD symptoms for low trust and high trust participants, respectively.

\begin{tabular}{|c|c|c|c|c|c|c|c|c|}
\hline \multirow{3}{*}{ Variables } & Model 1 & Model 2 & Model 3 & \multirow{3}{*}{$\begin{array}{l}\text { Model } 4 \\
\text { Arousal }\end{array}$} & \multirow[b]{3}{*}{ PCL-C Score } & \multirow{2}{*}{\multicolumn{2}{|c|}{$\begin{array}{l}\text { Model } 6 \quad \text { Model } 7 \\
\text { High Trust }\end{array}$}} & \multirow{3}{*}{$\begin{array}{l}\text { Model } 8 \\
\text { Arousal }\end{array}$} \\
\hline & \multicolumn{3}{|c|}{$\begin{array}{c}\text { Model } 2 \\
\text { Low Trust }\end{array}$} & & & & & \\
\hline & PCL-C Score & Reexperiencing & Avoidance & & & Reexperiencing & Avoidance & \\
\hline \multicolumn{9}{|l|}{ Independent variables } \\
\hline Media exposure & $\begin{array}{c}0.04 \\
(0.03)\end{array}$ & $\begin{array}{l}0.07 * \\
(0.03)\end{array}$ & $\begin{array}{c}0.02 \\
(0.03)\end{array}$ & $\begin{array}{l}0.06+ \\
(0.03)\end{array}$ & $\begin{array}{c}-0.05+ \\
(0.03)\end{array}$ & $\begin{array}{l}-0.03 \\
(0.03)\end{array}$ & $\begin{array}{c}-0.06^{*} \\
(0.03)\end{array}$ & $\begin{array}{l}-0.06 \\
(0.03)\end{array}$ \\
\hline \multicolumn{9}{|c|}{ Demographic and socioeconomic variables } \\
\hline Male & $\begin{array}{l}-0.00 \\
(0.06)\end{array}$ & $\begin{array}{c}0.02 \\
(0.06)\end{array}$ & $\begin{array}{c}0.01 \\
(0.06)\end{array}$ & $\begin{array}{l}-0.04 \\
(0.06)\end{array}$ & $\begin{array}{c}0.08 \\
(0.05)\end{array}$ & $0.13 *$ & $\begin{array}{c}0.03 \\
(0.06)\end{array}$ & $0.11+$ \\
\hline Age & $0.01 *$ & $0.01+$ & $0.01+$ & $0.01 * *$ & $0.01 *$ & 0.01 & $0.01^{*}$ & $0.01+$ \\
\hline Rural site & 0.10 & 0.10 & 0.06 & $0.15+$ & 0.05 & 0.05 & 0.05 & 0.03 \\
\hline & $(0.06)$ & $(0.07)$ & $(0.07)$ & $(0.07)$ & $(0.06)$ & $(0.07)$ & $(0.06)$ & $(0.07)$ \\
\hline Married & -0.11 & $-0.17^{*}$ & -0.09 & -0.09 & -0.01 & -0.09 & 0.05 & -0.02 \\
\hline & $(0.07)$ & $(0.08)$ & $(0.08)$ & $(0.08)$ & $(0.07)$ & $(0.08)$ & $(0.07)$ & $(0.09)$ \\
\hline \multicolumn{9}{|c|}{ Educational background $(0=$ primary school and below $)$} \\
\hline Junior high school & 0.14 & 0.06 & 0.12 & 0.24 * & 0.09 & 0.13 & 0.07 & 0.10 \\
\hline & $(0.10)$ & $(0.11)$ & $(0.11)$ & $(0.11)$ & $(0.09)$ & $(0.10)$ & $(0.10)$ & $(0.11)$ \\
\hline Senior high school & $0.31 * *$ & $0.22+$ & $0.29 *$ & $0.44^{* * *}$ & 0.13 & 0.16 & 0.13 & 0.11 \\
\hline & $(0.11)$ & $(0.13)$ & $(0.13)$ & $(0.13)$ & $(0.10)$ & $(0.12)$ & $(0.11)$ & $(0.13)$ \\
\hline Associate college and above & $0.57^{* * *}$ & $0.36^{*}$ & $0.56^{* * *}$ & $0.80 * * *$ & 0.19 & 0.20 & 0.21 & 0.19 \\
\hline & $(0.13)$ & $(0.15)$ & $(0.15)$ & $(0.15)$ & $(0.12)$ & $(0.14)$ & $(0.13)$ & $(0.15)$ \\
\hline \multicolumn{9}{|c|}{ Annual household income $(0=$ less than 40,000 RMB $)$} \\
\hline $40,000-59,999$ RMB & $-0.15+$ & -0.14 & $-0.21 *$ & -0.08 & -0.02 & -0.02 & 0.02 & -0.06 \\
\hline & $(0.08)$ & $(0.09)$ & $(0.09)$ & $(0.09)$ & $(0.08)$ & $(0.09)$ & $(0.08)$ & $(0.10)$ \\
\hline $60,000-89,999$ RMB & $-0.31^{* * *}$ & $-0.39 * * *$ & $-0.34^{* * *}$ & $-0.20 *$ & -0.07 & -0.03 & -0.04 & $-0.19+$ \\
\hline & $(0.08)$ & $(0.10)$ & $(0.10)$ & $(0.10)$ & $(0.09)$ & $(0.10)$ & $(0.09)$ & $(0.11)$ \\
\hline 90,000 RMB and above & -0.10 & -0.08 & -0.16 & -0.00 & 0.01 & 0.11 & -0.01 & -0.07 \\
\hline & $(0.10)$ & $(0.12)$ & $(0.11)$ & $(0.12)$ & $(0.09)$ & $(0.11)$ & $(0.10)$ & $(0.12)$ \\
\hline \multicolumn{9}{|l|}{ Earthquake exposure } \\
\hline Being buried & 0.08 & -0.04 & 0.12 & 0.15 & 0.02 & -0.03 & -0.01 & 0.14 \\
\hline & $(0.15)$ & $(0.17)$ & $(0.17)$ & $(0.18)$ & $(0.20)$ & $(0.23)$ & $(0.22)$ & $(0.25)$ \\
\hline Being injured & $-0.16^{*}$ & $-0.16+$ & $-0.17^{*}$ & -0.14 & -0.10 & -0.01 & -0.09 & $-0.21 *$ \\
\hline & $(0.08)$ & $(0.09)$ & $(0.09)$ & $(0.09)$ & $(0.08)$ & $(0.09)$ & $(0.09)$ & $(0.10)$ \\
\hline \multirow[t]{2}{*}{ Being disabled } & 0.03 & -0.07 & 0.12 & -0.02 & 0.58 & 0.56 & $0.77+$ & 0.31 \\
\hline & $(0.15)$ & $(0.17)$ & $(0.17)$ & $(0.17)$ & $(0.42)$ & $(0.48)$ & $(0.46)$ & $(0.52)$ \\
\hline \multirow[t]{2}{*}{ Family died } & 0.17 & 0.10 & 0.15 & $0.26+$ & -0.05 & -0.02 & 0.02 & -0.23 \\
\hline & $(0.12)$ & $(0.13)$ & $(0.13)$ & $(0.14)$ & $(0.13)$ & $(0.15)$ & $(0.14)$ & $(0.16)$ \\
\hline
\end{tabular}


Table A1. Cont.

\begin{tabular}{|c|c|c|c|c|c|c|c|c|}
\hline \multirow{3}{*}{ Variables } & Model 1 & Model 2 & Model 3 & \multirow[t]{2}{*}{ Model 4} & Model 5 & Model 6 & Model 7 & \multirow{2}{*}{ Model \& } \\
\hline & \multicolumn{3}{|c|}{ Low Trust } & & \multicolumn{3}{|c|}{ High Trust } & \\
\hline & PCL-C Score & Reexperiencing & Avoidance & Arousal & PCL-C Score & Reexperiencing & Avoidance & Arousal \\
\hline \multirow[t]{2}{*}{ Family injured } & 0.19 * & $0.30^{* * *}$ & 0.11 & $0.19 *$ & 0.08 & 0.11 & 0.01 & 0.15 \\
\hline & $(0.07)$ & $(0.08)$ & $(0.08)$ & $(0.09)$ & $(0.08)$ & $(0.09)$ & $(0.09)$ & $(0.10)$ \\
\hline \multirow[t]{2}{*}{ Family disabled } & -0.04 & -0.09 & -0.02 & -0.01 & $-0.19+$ & $-0.23+$ & -0.14 & $-0.25+$ \\
\hline & $(0.12)$ & $(0.14)$ & $(0.14)$ & $(0.14)$ & $(0.11)$ & $(0.13)$ & $(0.12)$ & $(0.14)$ \\
\hline \multirow[t]{2}{*}{ Kinsfolk died } & -0.06 & -0.02 & -0.05 & -0.13 & $-0.23^{* *}$ & $-0.20 *$ & $-0.20 *$ & $-0.32 * *$ \\
\hline & $(0.08)$ & $(0.09)$ & $(0.09)$ & $(0.09)$ & $(0.08)$ & $(0.09)$ & $(0.09)$ & $(0.10)$ \\
\hline \multirow[t]{2}{*}{ Kinsfolk injured } & $-0.17^{* *}$ & $-0.21 * *$ & $-0.14 *$ & $-0.18^{* *}$ & $-0.14^{*}$ & $-0.11+$ & $-0.13^{*}$ & $-0.16^{*}$ \\
\hline & $(0.06)$ & $(0.07)$ & $(0.07)$ & $(0.07)$ & $(0.06)$ & $(0.07)$ & $(0.06)$ & $(0.07)$ \\
\hline Kinsfolk disabled & $\begin{array}{l}-0.02 \\
(0.08)\end{array}$ & 0.00 & $\begin{array}{l}-0.01 \\
(0.09)\end{array}$ & $\begin{array}{l}-0.05 \\
(0.09)\end{array}$ & $-0.14+$ & $-0.22 * *$ & $\begin{array}{l}-0.07 \\
(0.08)\end{array}$ & $-0.16+$ \\
\hline \multirow[t]{2}{*}{ Acquaintance died } & $-0.24 * * *$ & $-0.22 * *$ & $-0.25^{* *}$ & $-0.28^{* *}$ & -0.03 & 0.05 & -0.06 & -0.04 \\
\hline & $(0.07)$ & $(0.08)$ & $(0.08)$ & $(0.09)$ & $(0.06)$ & $(0.07)$ & $(0.07)$ & $(0.08)$ \\
\hline \multirow[t]{2}{*}{ Acquaintance injured } & -0.03 & 0.03 & -0.07 & -0.05 & 0.01 & 0.09 & -0.03 & -0.02 \\
\hline & $(0.06)$ & $(0.07)$ & $(0.07)$ & $(0.07)$ & $(0.05)$ & $(0.06)$ & $(0.06)$ & $(0.07)$ \\
\hline \multirow[t]{2}{*}{ Acquaintance disabled } & 0.02 & -0.02 & 0.04 & 0.01 & 0.03 & 0.03 & 0.01 & 0.05 \\
\hline & $(0.06)$ & $(0.07)$ & $(0.07)$ & $(0.07)$ & $(0.06)$ & $(0.06)$ & $(0.06)$ & $(0.07)$ \\
\hline \multirow[t]{2}{*}{ Witness to others' burial } & -0.03 & -0.10 & 0.02 & -0.02 & $-0.13+$ & -0.08 & $-0.19^{*}$ & -0.14 \\
\hline & $(0.09)$ & $(0.11)$ & $(0.10)$ & $(0.11)$ & $(0.07)$ & $(0.08)$ & $(0.08)$ & $(0.09)$ \\
\hline \multirow[t]{2}{*}{ Witness to others' death } & $-0.16^{*}$ & $-0.14+$ & $-0.19^{*}$ & $-0.16+$ & -0.03 & -0.00 & -0.03 & -0.07 \\
\hline & $(0.07)$ & $(0.08)$ & $(0.08)$ & $(0.08)$ & $(0.06)$ & $(0.07)$ & $(0.07)$ & $(0.08)$ \\
\hline \multirow[t]{2}{*}{ Witness to others' injury } & 0.02 & -0.03 & 0.03 & 0.04 & -0.08 & -0.09 & -0.10 & -0.02 \\
\hline & $(0.06)$ & $(0.07)$ & $(0.07)$ & $(0.07)$ & $(0.06)$ & $(0.07)$ & $(0.07)$ & $(0.07)$ \\
\hline \multicolumn{9}{|c|}{ Loss of house and property $(0=$ mildly $)$} \\
\hline \multirow[t]{2}{*}{ Moderate } & $0.16^{*}$ & 0.13 & $0.19 *$ & $0.15+$ & $0.39^{* * *}$ & $0.40^{* * *}$ & $0.37^{* * *}$ & $0.46^{* * *}$ \\
\hline & $(0.08)$ & $(0.09)$ & $(0.09)$ & $(0.09)$ & $(0.06)$ & $(0.07)$ & $(0.07)$ & $(0.08)$ \\
\hline \multirow[t]{2}{*}{ Serious } & $0.22 * *$ & $0.22 *$ & $0.21 *$ & $0.21 *$ & $0.56^{* * *}$ & $0.51^{* * *}$ & $0.54^{* * *}$ & $0.70^{* * *}$ \\
\hline & $(0.08)$ & $(0.09)$ & $(0.09)$ & $(0.09)$ & $(0.07)$ & $(0.08)$ & $(0.08)$ & $(0.09)$ \\
\hline \multirow[t]{2}{*}{ Constant } & $1.81^{* * *}$ & $1.89^{* * *}$ & $2.01^{* * *}$ & $1.43^{* * *}$ & $1.86^{* * *}$ & $1.79^{* * *}$ & $1.88^{* * *}$ & $1.84^{* * *}$ \\
\hline & $(0.26)$ & $(0.30)$ & $(0.30)$ & $(0.31)$ & $(0.25)$ & $(0.28)$ & $(0.27)$ & $(0.31)$ \\
\hline Observations & 425 & 425 & 425 & 425 & 575 & 575 & 575 & 575 \\
\hline $\mathrm{df}$ & 28 & 28 & 28 & 28 & 28 & 28 & 28 & 28 \\
\hline chi2 & 97.87 & 89.84 & 78.43 & 87.40 & 108.7 & 91 & 91.13 & 104.4 \\
\hline Log likelihood & -347.4 & -404.5 & -397.5 & -416.8 & -504.3 & -582 & -558.5 & -634 \\
\hline PR2 & 0.123 & 0.100 & 0.0898 & 0.0949 & 0.0973 & 0.0725 & 0.0754 & 0.0761 \\
\hline
\end{tabular}

Standard errors in parentheses; ${ }^{* * *} p<0.001,{ }^{* *} p<0.01,{ }^{*} p<0.05,+p<0.1$ 


\section{Appendix B}

Table A2. Probit model of predicting high trust by demographic and socioeconomic variables and disaster exposure variables.

\begin{tabular}{|c|c|}
\hline Variables & High Trust $(1=$ yes $)$ \\
\hline \multicolumn{2}{|c|}{ Demographic and socioeconomic variables } \\
\hline Male & $\begin{array}{c}-0.26^{* *} \\
(0.08)\end{array}$ \\
\hline Age & $\begin{array}{c}0.00 \\
(0.01)\end{array}$ \\
\hline Rural site & $\begin{array}{l}-0.06 \\
(0.10)\end{array}$ \\
\hline Married & $\begin{array}{c}0.09 \\
(0.11)\end{array}$ \\
\hline \multicolumn{2}{|c|}{ Educational background ( $0=$ primary school and below) } \\
\hline Junior high school & $\begin{array}{c}-0.24+ \\
(0.14)\end{array}$ \\
\hline Senior high school & $\begin{array}{l}-0.23 \\
(0.17)\end{array}$ \\
\hline Associate college and above & $\begin{array}{c}0.01 \\
(0.20)\end{array}$ \\
\hline \multicolumn{2}{|c|}{ Annual household income ( $0=$ less than 40,000 RMB) } \\
\hline $40,000-59,999$ RMB & $\begin{array}{l}0.20+ \\
(0.12)\end{array}$ \\
\hline $60,000-89,999 \mathrm{RMB}$ & $\begin{array}{l}0.23+ \\
(0.14)\end{array}$ \\
\hline 90,000 RMB and above & $\begin{array}{l}0.36^{*} \\
(0.15)\end{array}$ \\
\hline \multicolumn{2}{|l|}{ Earthquake exposure } \\
\hline Being buried & $\begin{array}{l}-0.37 \\
(0.28)\end{array}$ \\
\hline Being injured & $\begin{array}{l}-0.01 \\
(0.12)\end{array}$ \\
\hline Being disabled & $\begin{array}{c}-1.33^{* *} \\
(0.41)\end{array}$ \\
\hline Family died & $\begin{array}{c}0.12 \\
(0.19)\end{array}$ \\
\hline Family injured & $\begin{array}{c}-0.04 \\
(0.12)\end{array}$ \\
\hline Family disabled & $\begin{array}{c}0.10 \\
(0.18)\end{array}$ \\
\hline Kinsfolk died & $\begin{array}{l}-0.06 \\
(0.13)\end{array}$ \\
\hline Kinsfolk injured & $\begin{array}{l}-0.06 \\
(0.09)\end{array}$ \\
\hline Kinsfolk disabled & $\begin{array}{l}-0.17 \\
(0.12)\end{array}$ \\
\hline Acquaintance died & $\begin{array}{c}0.15 \\
(0.11)\end{array}$ \\
\hline Acquaintance injured & $\begin{array}{c}0.09 \\
(0.09)\end{array}$ \\
\hline Acquaintance disabled & $\begin{array}{l}-0.06 \\
(0.09)\end{array}$ \\
\hline Witness to others' burial & $\begin{array}{c}0.09 \\
(0.13)\end{array}$ \\
\hline Witness to others' death & $\begin{array}{c}0.03 \\
(0.10)\end{array}$ \\
\hline Witness to others' injury & $\begin{array}{l}-0.02 \\
(0.10)\end{array}$ \\
\hline
\end{tabular}


Table A2. Cont.

\begin{tabular}{cc}
\hline Variables & High Trust $(\mathbf{1}=$ yes $)$ \\
\hline Loss of house and property $(0=$ mildly $)$ & -0.14 \\
Moderate & $(0.11)$ \\
Serious & $-0.29 *$ \\
& $(0.12)$ \\
Constant & 0.19 \\
& $0.37)$ \\
Observations & 1000 \\
df & 27 \\
chi2 & 72.94 \\
Log likelihood & -645.4 \\
PR2 & 0.0535 \\
\hline
\end{tabular}

Standard errors in parentheses; ${ }^{* * *} p<0.001,{ }^{* *} p<0.01,{ }^{*} p<0.05,+p<0.1$.

\section{References}

1. Sanderson, D.; Sharma, A. IFRC World Disasters Report, Resilience: Saving Lives Today, Investing for Tomorrow; International Federation of Red Cross and Red Crescent Societies (IFRC): Geneva, Switzerland, 2016.

2. Ando, S.; Saito, Y.; Nakamura, H.; Sone, M.; Sunmoto, E.Y. Report on the 2008 Great Sichuan Earthquake; United Nations Centre for Regional Development (UNCRD): Nagoya, Japan, 2009.

3. China News Service Wenchuan Earthquake Has already Caused 69,227 Fatalities and 17,923 Missing. Available online: http:/ / www.chinanews.com/gn/news/2008/09-25/1394600.shtml (accessed on 10 September 2018).

4. American Psychiatric Association. Diagnostic and Statistical Manual of Mental Disorders: DSM-5; American Psychiatric Association: Washington, DC, USA, 2013; ISBN 9780890425541.

5. Flores, E.C.; Carnero, A.M.; Bayer, A.M. Social capital and chronic post-traumatic stress disorder among survivors of the 2007 earthquake in Pisco, Peru. Soc. Sci. Med. 2014, 101, 9-12. [CrossRef] [PubMed]

6. Davidson, J.R.T.; McFarlane, A.C. The extent and impact of mental health problems after disaster. J. Clin. Psychiatry 2006, 67 (Suppl. 2), S9-S14.

7. Norris, F.H.; Friedman, M.J.; Watson, P.J.; Byrne, C.M.; Diaz, E.; Kaniasty, K. 60,000 Disaster Victims Speak: Part I. An Empirical Review of the Empirical Literature, 1981-2001. Psychiatry Interpers. Biol. Process. 2002, 65, 207-239. [CrossRef]

8. Udomratn, P. Mental health and the psychosocial consequences of natural disasters in Asia. Int. Rev. Psychiatry 2008, 20, 441-444. [CrossRef] [PubMed]

9. Tang, B.; Deng, Q.; Glik, D.; Dong, J.; Zhang, L. A meta-analysis of risk factors for post-traumatic stress disorder (PTSD) in adults and children after earthquakes. Int. J. Environ. Rese. Public Health 2017, 14, 1537. [CrossRef] [PubMed]

10. Kira, I.A.; Templin, T.; Lewandowski, L.; Ramaswamy, V.; Ozkan, B.; Mohanesh, J. The physical and mental health effects of Iraq war media exposure on Iraqi refugees. J. Muslim Ment. Health 2008, 3, 193-215. [CrossRef]

11. Nevdal, R.; Gravdal, H.W.; Laberg, J.C.; Dyregrov, K. Should the population limit its exposure to media coverage after a terrorist attack? Scand. Psychol. 2016, 3, e6. [CrossRef]

12. Pfefferbaum, B.; Nitiéma, P.; Pfefferbaum, R.L.; Houston, J.B.; Tucker, P.; Jeon-Slaughter, H.; North, C.S. Reactions of Oklahoma City bombing survivors to media coverage of the September 11, 2001, attacks. Compr. Psychiatry 2016, 65, 70-78. [CrossRef] [PubMed]

13. Wang, L.; Zhang, Y.; Shi, Z.; Wang, W. Symptoms of Posttraumatic Stress Disorder among Adult Survivors Two Months after the Wenchuan Earthquake. Psychol. Rep. 2009, 105, 879-885. [CrossRef] [PubMed]

14. Wang, L.; Zhang, J.; Zhou, M.; Shi, Z.; Liu, P. Symptoms of Posttraumatic Stress Disorder among Health Care Workers in Earthquake-Affected Areas in Southwest China. Psychol. Rep. 2010, 106, 555-561. [CrossRef] [PubMed] 
15. Wang, L.; Zhang, Y.; Wang, W.; Shi, Z.; Shen, J.; Li, M.; Xin, Y. Symptoms of posttraumatic stress disorder among adult survivors three months after the Sichuan earthquake in China. J. Traum. Stress 2009, 22, 444-450. [CrossRef] [PubMed]

16. Guo, J.; He, H.; Qu, Z.; Wang, X.; Liu, C. Post-traumatic stress disorder and depression among adult survivors 8 years after the 2008 Wenchuan earthquake in China. J. Affect. Disord. 2017, 210, 27-34. [CrossRef] [PubMed]

17. Wang, W.; Fu, W.; Wu, J.; Ma, X.-C.; Sun, X.-L.; Huang, Y.; Hashimoto, K.; Gao, C.-G. Prevalence of ptsd and depression among junior middle school students in a rural town far from the epicenter of the Wenchuan Earthquake in China. PLoS ONE 2012, 7, e41665. [CrossRef]

18. An, Y.; Fu, F.; Wu, X.; Lin, C.; Zhang, Y. Longitudinal Relationships between Neuroticism, Avoidant Coping, and Posttraumatic Stress Disorder Symptoms in Adolescents Following the 2008 Wenchuan Earthquake in China. J. Loss Trauma 2013, 18, 556-571. [CrossRef]

19. Hamilton, J.D.; Workman, R.H., Jr. Persistence of combat-related posttraumatic stress symptoms for 75 years. J. Traum. Stress 1998, 11, 763-768. [CrossRef] [PubMed]

20. Pan, X.; Liu, W.; Deng, G.; Liu, T.; Yan, J.; Tang, Y.; Dong, W.; Cui, Y.; Xu, M. Symptoms of posttraumatic stress disorder, depression, and anxiety among junior high school students in worst-hit areas 3 years after the Wenchuan earthquake in china. Asia-Pac. J. Public Health 2015, 27, NP1985-NP1994. [CrossRef] [PubMed]

21. Neria, Y.; Sullivan, G.M. Understanding the Mental Health Effects of Indirect Exposure to Mass Trauma Through the Media. JAMA 2011, 306, 1374. [CrossRef] [PubMed]

22. Ben-Zur, H.; Gil, S.; Shamshins, Y. The relationship between exposure to terror through the media, coping strategies and resources, and distress and secondary traumatization. Int. J. Stress Manag. 2012, 19, 132-150. [CrossRef]

23. Ahern, J.; Galea, S.; Resnick, H.; Vlahov, D. Television Images and Probable Posttraumatic Stress Disorder after September 11: The Role of Background Characteristics, Event Exposures, and Perievent Panic. J. Nervous Ment. Dis. 2004, 192, 217-226. [CrossRef]

24. Silver, R.C.; Holman, E.A.; Andersen, J.P.; Poulin, M.; McIntosh, D.N.; Gil-Rivas, V. Mental- and Physical-Health Effects of Acute Exposure to Media Images of the September 11, 2001, Attacks and the Iraq War. Psychol. Sci. 2013, 24, 1623-1634. [CrossRef] [PubMed]

25. Saylor, C.F.; Cowart, B.L.; Lipovsky, J.A.; Jackson, C.; Finch, A.J. Media exposure to September 11: Elementary school students' experiences and posttraumatic symptoms. Am. Behav. Sci. 2003, 46, 1622-1642. [CrossRef]

26. Propper, R.E.; Stickgold, R.; Keeley, R.; Christman, S.D. Is Television Traumatic?: Dreams, Stress, and Media Exposure in the Aftermath of September 11, 2001. Psychol. Sci. 2007, 18, 334-340. [CrossRef] [PubMed]

27. Boyle, M.P.; Schmierbach, M.; Armstrong, C.L.; McLeod, D.M.; Shah, D.V.; Pan, Z. Information Seeking and Emotional Reactions to the September 11 Terrorist Attacks. Journal. Mass Commun. Q. 2004, 81, 155-167. [CrossRef]

28. Kubey, R.; Peluso, T. Emotional response as a cause of interpersonal news diffusion: The case of the space shuttle tragedy. J. Broadcast. Media 1990, 34, 69-76. [CrossRef]

29. Liang, Y. Trust in Chinese Government and Quality of Life (QOL) of Sichuan Earthquake Survivors: Does Trust in Government Help to Promote QOL? Soc. Indic. Res. 2016, 127, 541-564. [CrossRef]

30. Lindstrom, M.; Axelsson, J.; Moden, B.; Rosvall, M. Sexual orientation, social capital and daily tobacco smoking: A population-based study. BMC Public Health 2014, 14, 565. [CrossRef] [PubMed]

31. Carpiano, R.M. Toward a neighborhood resource-based theory of social capital for health: Can Bourdieu and sociology help? Soc. Sci. Med. 2006, 62, 165-175. [CrossRef] [PubMed]

32. Kopacz, M.S.; Ames, D.; Koenig, H.G. Association Between Trust and Mental, Social, and Physical Health Outcomes in Veterans and Active Duty Service Members with Combat-Related PTSD Symptomatology. Front. Psychiatry 2018, 9, 408. [CrossRef] [PubMed]

33. Kuhl, M.; Boyraz, G. Mindfulness, General Trust, and Social Support Among Trauma-Exposed College Students. J. Loss Trauma 2017, 22, 150-162. [CrossRef]

34. Kuhlicke, C.; Steinführer, A.; Begg, C.; Bianchizza, C.; Bründl, M.; Buchecker, M.; De Marchi, B.; Di Masso Tarditti, M.; Höppner, C.; Komac, B.; et al. Perspectives on social capacity building for natural hazards: Outlining an emerging field of research and practice in Europe. Environ. Sci. Policy 2011, 14, 804-814. [CrossRef]

35. Babcicky, P.; Seebauer, S. The two faces of social capital in private flood mitigation: Opposing effects on risk perception, self-efficacy and coping capacity. J. Risk Res. 2017, 20, 1017-1037. [CrossRef] 
36. Norris, F.H.; Stevens, S.P.; Pfefferbaum, B.; Wyche, K.F.; Pfefferbaum, R.L. Community resilience as a metaphor, theory, set of capacities, and strategy for disaster readiness. Am. J. Community Psychol. 2008, 41, 127-150. [CrossRef] [PubMed]

37. Sawada, Y. Is trust really social capital? Commentary on Carpiano and Fitterer (2014). Soc. Sci. Med. 2014, 116, 237-238. [CrossRef] [PubMed]

38. Luo, J.D. Particularistic Trust and General Trust: A Network Analysis in Chinese Organizations. Manag. Organ. Rev. 2005, 1, 437-458. [CrossRef]

39. Takakura, M. Does social trust at school affect students' smoking and drinking behavior in Japan? Soc. Sci. Med. 2011, 72, 299-306. [CrossRef] [PubMed]

40. Kim, D.; Baum, C.F.; Ganz, M.L.; Subramanian, S.V.; Kawachi, I. The contextual effects of social capital on health: A cross-national instrumental variable analysis. Soc. Sci. Med. 2011, 73, 1689-1697. [CrossRef] [PubMed]

41. Flynn, J.; Burns, W.; Mertz, C.K.; Slovic, P. Trust as a Determinant of Opposition to a High-Level Radioactive Waste Repository: Analysis of a Structural Model. Risk Anal. 1992, 12, 417-429. [CrossRef]

42. Vasterman, P.; Yzermans, C.J.; Dirkzwager, A.J.E. The role of the media and media hypes in the aftermath of disasters. Epidemiol. Rev. 2005, 27, 107-114. [CrossRef] [PubMed]

43. Miura, I.; Nagai, M.; Maeda, M.; Harigane, M.; Fujii, S.; Oe, M.; Yabe, H.; Suzuki, Y.; Takahashi, H.; Ohira, T.; et al. Perception of radiation risk as a predictor of mid-term mental health after a nuclear disaster: The fukushima health management survey. Int. J. Environ. Res. Public Health 2017, 14, 1067. [CrossRef] [PubMed]

44. Binder, A.R.; Scheufele, D.A.; Brossard, D.; Gunther, A.C. Interpersonal Amplification of Risk? Citizen Discussions and Their Impact on Perceptions of Risks and Benefits of a Biological Research Facility. Risk Anal. 2011, 31, 324-334. [CrossRef] [PubMed]

45. PRC, T.S.C. of Overall Post-Disaster Recovery and Reconstruction Planning for Wenchuan Earthquake. Available online: http:/ /www.gov.cn/zwgk/2008-09/23/content_1103686.htm (accessed on 5 September 2018).

46. Weathers, F.W.; Litz, B.T.; Herman, D.S.; Huska, J.A.; Keane, T.M. The PTSD Checklist: Reliability, validity, and diagnostic utility. Int. Soc. Traum. Stress Stud. 1993, 2, 90-92.

47. Forbes, D.; Creamer, M.; Biddle, D. The validity of the PTSD checklist as a measure of symptomatic change in combat-related PTSD. Behav. Res. Ther. 2001, 39, 977-986. [CrossRef]

48. Xu, J.; Song, X. Posttraumatic stress disorder among survivors of the Wenchuan earthquake 1 year after: Prevalence and risk factors. Compr. Psychiatry 2011, 52, 431-437. [CrossRef] [PubMed]

49. Ahern, J.; Galea, S.; Resnick, H.; Kilpatrick, D.; Bucuvalas, M.; Gold, J.; Vlahov, D. Television Images and Psychological Symptoms after the September 11 Terrorist Attacks. Psychiatry Interpers. Biol. Process. 2002, 65, 289-300. [CrossRef]

50. Collimore, K.C.; McCabe, R.E.; Carleton, R.N.; Asmundson, G.J.G. Media exposure and dimensions of anxiety sensitivity: Differential associations with PTSD symptom clusters. J. Anxiety Disord. 2008, 22, 1021-1028. [CrossRef] [PubMed]

51. Giordano, G.N.; Merlo, J.; Ohlsson, H.; Rosvall, M.; Lindstrom, M. Testing the association between social capital and health over time: A family-based design. BMC Public Health 2013, 13, 665. [CrossRef] [PubMed]

52. Zhang, Y.; Ho, S.M.Y. Risk Factors of Posttraumatic Stress Disorder among Survivors after the 512 Wenchuan Earthquake in China. PLoS ONE 2011, 6, e22371. [CrossRef] [PubMed]

53. Kun, P.; Chen, X.; Han, S.; Gong, X.; Chen, M.; Zhang, W.; Yao, L. Prevalence of post-traumatic stress disorder in Sichuan Province, China after the 2008 Wenchuan earthquake. Public Health 2009, 123, 703-707. [CrossRef] [PubMed]

54. Jarque, C.M.; Bera, A.K. A test for normality of observations and regression residuals. Int. Stat. Rev./Revue Internationale de Statistique 1987, 55, 163-172. [CrossRef]

55. McDonald, J.F.; Moffitt, R.A. The Uses of Tobit Analysis. Rev. Econ. Stat. 1980, 62, 318. [CrossRef]

56. Kristensen, P.; Dyregrov, K.; Dyregrov, A.; Heir, T. Media exposure and prolonged grief: A study of bereaved parents and siblings after the 2011 utøya island terror attack. Psychol. Trauma Theory Res. Pract. Policy 2016, 8, 661-667. [CrossRef] [PubMed]

57. Bodas, M.; Siman-Tov, M.; Peleg, K.; Solomon, Z. Anxiety-Inducing Media: The Effect of Constant News Broadcasting on the Well-Being of Israeli Television Viewers. Psychiatry 2015, 78, 265-276. [CrossRef] [PubMed] 
58. Pfefferbaum, B.; Tucker, P.; Pfefferbaum, R.L.; Nelson, S.D.; Nitiéma, P.; Newman, E. Media Effects in Youth Exposed to Terrorist Incidents: A Historical Perspective. Curr. Psychiatry Rep. 2018, 20, 11. [CrossRef] [PubMed]

59. Fan, F.; Zhang, Y.; Yang, Y.; Mo, L.; Liu, X. Symptoms of posttraumatic stress disorder, depression, and anxiety among adolescents following the 2008 Wenchuan earthquake in China. J. Traum. Stress 2011, 24, 44-53. [CrossRef] [PubMed]

60. Musalia, J. Social capital and health in Kenya: A multilevel analysis. Soc. Sci. Med. 2016, 167, 11-19. [CrossRef] [PubMed]

61. Putnam, R.D. Bowling alone: Americas's declining social capital. J. Democr. 1995, 6, 65-78. [CrossRef]

62. Fei, X. From the Soil, the Foundations of Chinese Society: A Translation of Fei Xiaotong's Xiangtu Zhongguo; University of California Press: Berkeley, CA, USA, 1992.

63. Hu, A.; Zhou, Y. Revisiting the Negative Effects of Confucian Culture on Generalized Trust: A study based on 2007 Chinese spiritual life survey. Sociol. Stud. 2013, 28, 28-54.

64. Brannon, L.A.; Tagler, M.J.; Eagly, A.H. The moderating role of attitude strength in selective exposure to information. J. Exp. Soc. Psychol. 2007, 43, 611-617. [CrossRef]

65. Maercker, A.; Mehr, A. What if victims read a newspaper report about their victimization? A study on the relationship to PTSD symptoms in crime victims. Eur. Psychol. 2006, 11, 137-142. [CrossRef]

66. Steinhardt, H.C. How is High Trust in China Possible? Comparing the Origins of Generalized Trust in Three Chinese Societies. Political Stud. 2012, 60, 434-454. [CrossRef]

(C) 2018 by the authors. Licensee MDPI, Basel, Switzerland. This article is an open access article distributed under the terms and conditions of the Creative Commons Attribution (CC BY) license (http:/ / creativecommons.org/licenses/by/4.0/). 